\title{
PENGARUH MODEL PEMBELAJARAN KOOPERATIF TIPE SNOWBALL THROWING TERHADAP HASIL BELAJAR IPS
}

\author{
Ni Putu Jita Apsari ${ }^{1}$, I Ketut Dibia ${ }^{2}$, Putu Aditya Antara ${ }^{3}$ \\ 1,2,3 Jurusan Pendidikan Guru Sekolah Dasar \\ Universitas Pendidikan Ganesha \\ Singaraja, Indonesia \\ e-mail: jitaapsari07@gmail.com¹, iketut.dibia@undiksha.ac.id², putuaditya.antara@undiksha.ac.id ${ }^{3}$
}

\begin{abstract}
Abstrak
Penelitian ini bertujuan untuk mengetahui perbedaan hasil belajar siswa yang dibelajarkan dengan model pembelajaran Kooperatif Tipe Snowball Throwing dengan model pembelajaran konvensional terhadap hasil belajar IPS siswa SD kelas V di Gugus II Kecamatan Kintamani Tahun Pelajaran 2018/2019. Jenis penelitian adalah eksperimen semu menggunakan post test only control group design. Populasi penelitian ini adalah seluruh siswa SD kelas V Gugus II Kecamatan Kintamani. Penentuan sampel dilakukan dengan teknik random sampling. Pengumpulan data dalam penelitian dilakukan dengan metode tes. Instrumen pengumpulan data berupa tes pilihan ganda. Data Hasil Belajar IPS dianalisis dengan uji-t. Hasil analisi menunjukkan bahwa terdapat perbedaan hasil belajar IPS antara kelompok siswa dibelajarkan dengan menggunakan model pembelajaran Kooperatif Tipe Snowball Throwing dan kelompok siswa dibelajarkan dengan menggunakan pembelajaran konvenional pada siswa SD kelas $\mathrm{V}$ Di Gugus II Kecamatan Kintamani. Hal ini ditunjukkan oleh thitung $(6,92)$ lebih besar dari nilai ttabel $(2,01)$. Rata-rata skor hasil belajar IPS siswa menggunakan model Snowball Throwing yaitu 24,56 lebih tinggi dari rata-rata hasil belajar IPS siswa menggunakan pembelajaran konvensional yaitu 18,22. Dengan demikian, model pembelajaran Snowball Throwing berpengaruh signifikan terhadap hasil belajar IPS siswa SD kelas V di Gugus II Kecamatan Kintamani Tahun Pelajaran 2018/2019.
\end{abstract}

Kata-kata kunci : hasil belajar IPS, snowball throwing

\begin{abstract}
This research was aimed to know the difference students' learning achievement on IPS between the students who were taught by using cooperative with Snowball Throwing type learning model and who were taught by using conventional learning on the student grade V in the Primary School of group II Kintamani sub-distric in the academic year 2018/2019. This research was a quasi experiment research with post-test only control group design. The population of this research was all of stundents in the Primary School of group II Kintamani sub-distric. By using random sampling technique, the sample was choosen. The data were collected by using test method. Data were obtained through objective test for IPS learning achievement at the end of the research. the collected data were tested by using t-test. The data analysed was showed that, there are difference students' learning achievement on IPS between the students who were taught by using cooperative with Snowball Throwing type learning model and who were taught by using conventional learning on the student grade $\mathrm{V}$ in the Primary School of group II Kintamani sub-distric. It is showed by tscore (6.92) which is greater that ttable (2.01). The mean score of students' learning achievement on IPS who were taught by using Snowball Throwing (24.56) which is higher than who were taught by using conventional learning (18.22). So that, Snowball Throwing learning model given a significance effect on students learning achievement on IPS on the student grade V in the Primary School of group II Kintamani sub-distric in the academic year 2018/2019. .
\end{abstract}

Keywords: learning achievement on IPS, Snowball Throwing 


\section{Pendahuluan}

Pada era globalisasi saat ini pendidikan merupakan hal yang utama dan menjadi kebutuhan bagi manusia. Tanpa adanya pendidikan, manusia tidak akan mengetahui berbagai macam ilmu pengetahuan yang ada di sekitarnya. Pendidikan sangatlah penting bagi manusia, sebab dengan adanya pendidikan, kemampuan berpikir manusia akan semakin meningkat dan dengan adanya pendidikan manuasia akan lebih mudah untuk mendapatkan pekerjaan yang nantinya dapat dipergunakan untuk melanjutkan kehidupannya.

Pendidikan merupakan sarana untuk membangun sumber daya manusia yang sepatutnya mendapatkan perhatian terus-menerus dari pemerintah. Pendidikan memegang peran penting dalam menciptakan sumber daya manusia berkualitas. Seiring berjalannya waktu dan perkembangannya ilmu pengetahuan dan teknologi (IPTEK). Persaingan dalam berbagai bidang kehidupan menjadi semakin ketat yang menurut manusia untuk menjadi pemenang dalam mempertahankan kehidupannya. Keberadaan sumber daya manusia (SDM) merupakan komponen yang sangat menentukan nasib suatu bangsa, sehingga setiap bangsa menuntut agar memiliki wawasan terhadap ilmu pengetahuan, dan dapat mengembangkannya dalam kehidupan. Sumber daya manusia yang berkualitas dapat dihasilakn salah satunya melalui pendidikan.

Undang-Undang No. 20 Tahun 2003 tentang Sistem Pendidikan Nasional, Pasal 1 angka 1 menyatakan bahwa pendidikan adalah usaha sadar dan terencana untuk mewujudkan suasana belajar dan proses pembelajaran agar peserta didik secara aktif mengembangkan potensi dirinya untuk memiliki kekuatan spiritual keagamaan, pengendalian diri, kepribadian, kecerdasan, akhlak mulia, serta keterampilan yang diperlukan dirinya, masyarakat, bangsa, dan negara.

Menurut UU No. 20 tahun 2003 tentang Sistem Pendidikan Nasional, Kurikulum merupakan "suatu alat pendidikan dalam rangka pengembangan sumber daya manusia yang berkualitas" Kurikulum menyediakan kesempatan yang luas bagi peserta didik untuk mengalami proses pendidikan dan pembelajaran untuk mencapai target tujuan pendidikan nasional khususnya dan sumber daya manusia yang berkualitas.

Untuk mewujudkan pendidikan dan proses pembelajaran yang berkualitas, salah satunya yang harus ada adalah guru yang profesional. Kunandar (dalam Sri Putra,2007) menyatakn bahwa guru yang profesional adalah guru yang memiliki kompetensi untuk menunjang tugasnya dalam mendidik peserta didik. Adapun kompetensi tersebut yakni kompetensi pedagogik, kompetensi keperibadian, kompetensi sosial dan kompetensi profesional. Dalam melaksanakan pembelajaran terhadap tiga aspek penting yang harus dilibatkan yaitu produk, proses dan sikap. Utnuk itu pendidikan yang berorientasi pada hasil dan sikap harus dilaksanakan dari jenjang pendidikan formal yang paling dasar yaitu sekolah dasar (SD).

Pembelajaran adalah suatu usaha yang dilakukan oleh seorang pendidik untuk menciptakan suasana belajar bagi peserta didiknya pada suatu lingkungan belajar yang meliputi guru dan siswa yang saling bertukar informasi. Menurut Muslich (dalam Rafianti :123) mengartikan pembelajaran adalah proses aktif bagi siswa dan guru untuk mengembangkan potensi siswa sehingga mereka akan "tahu" terhadap pengetahuan dan pada akhirnya "mampu" untuk melakukan sesuatu. Pembelajaran diarahkan agar mampu mengembangkan kemampuan peserta didk agar sesuai dengan potensi, perkembangan, kebutuhan dan kepentingan peserta didik serta tuntutan lingkungan. Dengan berkembangknya potensi dalam diri peserta didik maka diharpkan individiu tersebut mampu menghadapi tantangan jaman dengan mudah dan memiliki daya saing tinggi. Hal diatas sejalan dengan amanat pendidikan nasional yaitu pendidikan harus mampu menjamin pemerataan kesempatan pendidikan, peningkatan mutu serta relevansi dan efisiensi manajemen pendidikan untuk menghadapi tantangan sesuai dengan tuntutan perubahan kehidupan lokal, nasional, dan global.

IImu Pengetahuan Sosial (IPS) merupakan salah satu mata pelajaran yang diberikan mulai dari SD/MI/SDLB sampai SMP/MTs/SMPLB. IPS mengkasi seprangkat peristiwa, fakta, konsep, dan generealisasi yang berkaitan dengan isu sosial. Melalui mata pelajaran IPS, peserta didik diarahkan untuk dapat menjadi warga negara Indonesia yang demokratis dan 
bertanggung jawab serta warga dunia yang cintai damai. National Council for the Sosial Studies (NCSS) (2015) mengidentifikasikan sosial studies atau IImu Pengetahuan Sosial (IPS) sebagai suatu studi yang terintegrasi dari ilmu-ilmu sosial dan humaniora untuk meningkatkan kemampuan warga negara. Dalam program sekolah, IPS mengkaji secara sistematis dan terkoordinasi berbagai disiplin ilmu seperti georgafi, ekonomi, ilmu politik, ilmu hukum, sejarah, antropologi, psikologi, dan sebagainya. (Wahidmurni, 2017:17).

Selama ini, minat belajar siswa terhadap mata pelajaran IImu Pengetahuan Sosial (IPS) ini masih tergolong sangat rendah. Hal ini dapat dilihat di keseharian siswa selama mengikuti proses pembelajaran tidak fokus dan ramai sendiri. Bahkan ada sebagian siswa menganggap mata pelajaran IPS itu penting dikarenakan mata pelajaran IPS itu termasuk mata pelajaran yang di ujikan pada Ujian Nasional (UN). Selain itu bukti di lapangan juga menunjukkan rendahnya hasil belajar IPS siswa, berdasarkan data rata-rata hasil belajar yang diperoleh di SD Gugus II Kecamatan Kintamani diperoleh rata-rata yang jauh di bawah KKM. Metode yang konvensional seperti menjelaskan materi secara abstrak, hafalan materi dan ceramah dengan komunikasi satu arah, yang aktif masih didominasi oleh guru, sedangkan siswa biasanya hanya memfokuskan penglihatan dan pendengaran. Kondisi pembelajaran seperti inilah yang mengakibatkan siswa kurang aktif dan pembelajaran yang dilakukan kurang efektif. Disini guru dituntut untuk pandai menciptakan suatu pembelajaran yang menyenangkan bagi siswa sehingga siswa kembali berminat mengikuti kegiatan belajar.

Sehingga diperlukan suatu model pembelajaran yang dapat membantu guru dan siswa untuk meningkatkan dan menarik minat siswa dalam belajar IPS. Snowball Throwing adalah salah satu model pembelajaran kooperatif. Model pembelajaran Snowball Throwing merupakan model yang cara belajarnya melalui perainan yaitu saling lempar bola kertas yang berisi pertanyaan, hal ini bertujuan untuk mengajak siswa agar selalu siap dan tanggap menerima pesan dari orang lain. Kurniaasih\& Sani (2016) mengartikan model Snowball Throwing atau bola salju bergulir ini memadukan pendekatan komunikasi, integratif, dan keterampilan proses. "Model ini juga memberikan pengalaman kepada siswa untuk mengembangkan keterampilan menyimpulkan isi berita atau informasi yang mereka peroleh dalam konteks nyata dan situasi yang kompleks" (Kurniasih \& Sani, 2016:77).

Dalam penelitian ini, perlakuan yang diberikan pada kelas eksperimen berupa pembelajaran dengan menggunakan model pembelajaran kooperatif tipe Snowball Throwing merupakan variabel bebas, sedangkan pada kelas kontrol tanpa menggunakan model pembelajaran kooperatif tipe Snowball Throwing tetapi menggunakan pembelajaran konvensional merupakan variabel moderator dan hasil belajar pengetahuan IPS merupakan variabel terikat.

Diharapkan dengan menggunakan model pembelajaran Snowball Throwing dalam proses pembelajaran IPS akan menarik siswa mengikuti kegiatan belajar sehingga akan meningkatkan hasil belajar siswa. Berdasarkan latar belakang di atas, dilakukan penelitian eksperimen dengan judul "Pengaruh Model Pembelajaran Kooperatif Tipe Snowball Throwing Terhadap Hasil Belajar IPS Siswa".

Adapun tujuan yang ingin dicapai dalam penelitan ini adalah untuk mengetahui perbedaan hasil belajar siswa yang dibelajarkan dengan model pembelajaran Kooperatif Tipe Snowball Throwing dengan model pembelajaran konvensional terhadap hasil belajar IPS siswa.

\section{Metode}

Jenis penelitian ini adalah penelitian ekperimen semu dengan desain penelitian post-test only control group. Populasi dalam penelitian ini adalah siswa kelas V SD Gugus II Kecamatan Kintamani Tahun 2018/2019 yang terdiri dari 8 kelas seperti pada Table 1 berikut. 
Tabel 1. Sebaran Data Populasi

\begin{tabular}{rcc}
\hline No. & Nama Sekolah Dasar & Jumlah siswa kelas V \\
\hline 1. & SD Negeri 1 Batur & 22 \\
2. & SD Negeri 2 Batur & 13 \\
3. & SD Negeri 3 Batur & 23 \\
4. & SD Negeri 3 Batur & 23 \\
5. & SD Negeri 4 Batur & 11 \\
6. & SD Negeri 5 Batur & 15 \\
7 & SD Negeri 6 Batur & 25 \\
8 & SD Negeri 7 Batur & 34 \\
\hline
\end{tabular}

Selanjutnya seluruh kelompok dalam populasi tersebut diuji kesteraannya dengan menggunakan Anava satu jalur. Berdasarkan uji kesetaraan yang telah dilakukan dengan berbantuan aplikasi SPSS 17.0 for Windows diketahui bahwa signifikansi nilai hasil belajar pada populasi tersebut adalah 0,896 lebih besar dari $(0,896>0,05)$. Artinya hasil belajar IPS siswa SD kelas V di Gugus II Kecamatan Kintamani setara.

Untuk memperoleh sampel dalam penelitian ini, digunakan teknik random sampling. Dari banyaknya kelas V di Gugus II Kecamatan Kintamani dilakukan secara terpilih untuk diambil dua kelas yang akan dijadikan subjek penelitian. Dan diperoleh SD N 3 Batur Kelas V A sebagai kelas eksperimen dan SD N 3 Batur Kelas V B sebagai kelas kontrol.

Data yang dikumpulkan dalam penelitian ini adalah data mengenai hasil belajar pada mata pelajaran IPS. Data tersebut dikumpulkan mnggunakan metode tes. Agung (2014:92) menggunakan bahwa metode tes merupakan, "cara memperoleh data yang berbentuk suatu tugas yang harus dikerjakan seseorang atau kelompok orang yang dites (tastee), dan dari tes dapat menghasilkan suatu skor (interval)".

Instrumen yang digunakan untuk pengumpulan data tentang hasil belajar IPS adalah tes objektif (pilihan ganda). Dengan dilakukannya tes maka akan mengetahui penguasaan siswa terhadap pelajaran IPS yang mereka peroleh selama penelitian.

Sebelum instrument digunakan, terlebih dahulu dilakukan uji pakar untuk melihat kualitas isi dari instrument, kemudian instrument di ujikan ke beberapa orang siswa untuk mementukan validitas tiap butir soal yang akan diuji dengan menggunakan korelasi Point Biserial, uji reliabilitas menggunakan KR-20, uji tingkat kesukaran, dan diuji daya bedanya. Berdasarkan hasil uji coba intrumen, diperoleh dari 40 soal yang diujikan terdapat 30 soal yang valid, dan akan digunakan sebagai instrument post-test.

Data yang diperoleh dari penelitian ini adalah data kuantitatif berupa skor hasil belajar IPS kelas V. Data yang diperoleh diuji secara deskritif yang terdiri dari perhitungan mean, median modus, standar deviasi, varians, maksimum, minimum, dan jangkauan, serta secara inferensial untuk pengujain hipotesis yang diajukan. Sebelum melakukan pengujian hipotesis, terlebih dahulu dilakukan uji prasyarat yaitu uji normalitas dan uji homogenitas. Pengujian normalitas sebaran data dilakukan dengan Uji Chi-Square. Nilai $\chi^{2}$ hitung dibandingkan dengan nilai $\chi^{2}$ tabel pada taraf signifikan $5 \%$. Jika nilai $\chi^{2}$ hitung lebih kecil dari nilai $\chi^{2} t_{\text {abel }}$ maka hipotesis nol yang menyatakan bahwa data berasal dari populasi yang berdistribusi normal dapat diterima. Pengujian homogenitas data dilakukan dengan Uji $F$. Nilai $F_{\text {hitung }}$ dibandingkan dengan $F_{\text {tabel }}$ pada taraf signifikan $5 \%$. Jika $F_{\text {hitung }}<F_{\text {tabel }}$ maka $H_{0}$ diterima sehingga dapat disimpulkan bahwa varians data homogen. Pengujian hipotesis dilakukan denggan menggunakan uji-t independet. Kriteria pengujian adalah tolak $\mathrm{H}_{0}$ jika $t_{\text {hitung }}<t_{\text {tabel }}$, pada taraf signifikansi $5 \%$ dengan $\mathrm{db}=\mathrm{n} 1+\mathrm{n} 2-2$. 


\section{Hasil dan Pembahasan}

Data yang diperoleh dari hasi penelitian ini adalah data hasil belajar IPS siswa pada kelas kontrol dan siswa pada kelas eksperimen yang diperoleh dari hasil pemberian post-test. Pada tabel 2 berikut akan disajikan rangkuman hasil analisis deksritif, skor hasil belajar siswa pada kelompok eksperimen dan kelompok kontrol.

Tabel 2. Rangkuman Hasil Analisis Deskritif Skor Hasil Belajar IPS

\begin{tabular}{ccc}
\hline Variabel & Kelas Eksperimen & Kelas Kontrol \\
\hline $\mathrm{N}$ & 23 & 23 \\
Mean & 24,56 & 18,22 \\
Median & 25 & 19 \\
Modus & 24 & 16 \\
Standar Deviasi & 1,24 & 1,75 \\
Jangkauan & 4 & 6 \\
Minimum & 27 & 22 \\
Maksimum & 23 & 16 \\
\hline
\end{tabular}

Berdasarkan perhitungan tersebut, diproleh nilai rata-rata data hasil belajar IPS siswa pada kelompok eksperimen yang mengikuti pembelajaran dengan model pembelajaran snowball throwing adalah 24,56 sedangkan nilai rata-rata pada kelompok kontrol yang mengikuti pembelajaran konvensional adalah 18,22. Data hasil belajar IPS kelompok eksperimen dapat disajikan ke dalam bentuk grafik polygon seperti Gambar 1.

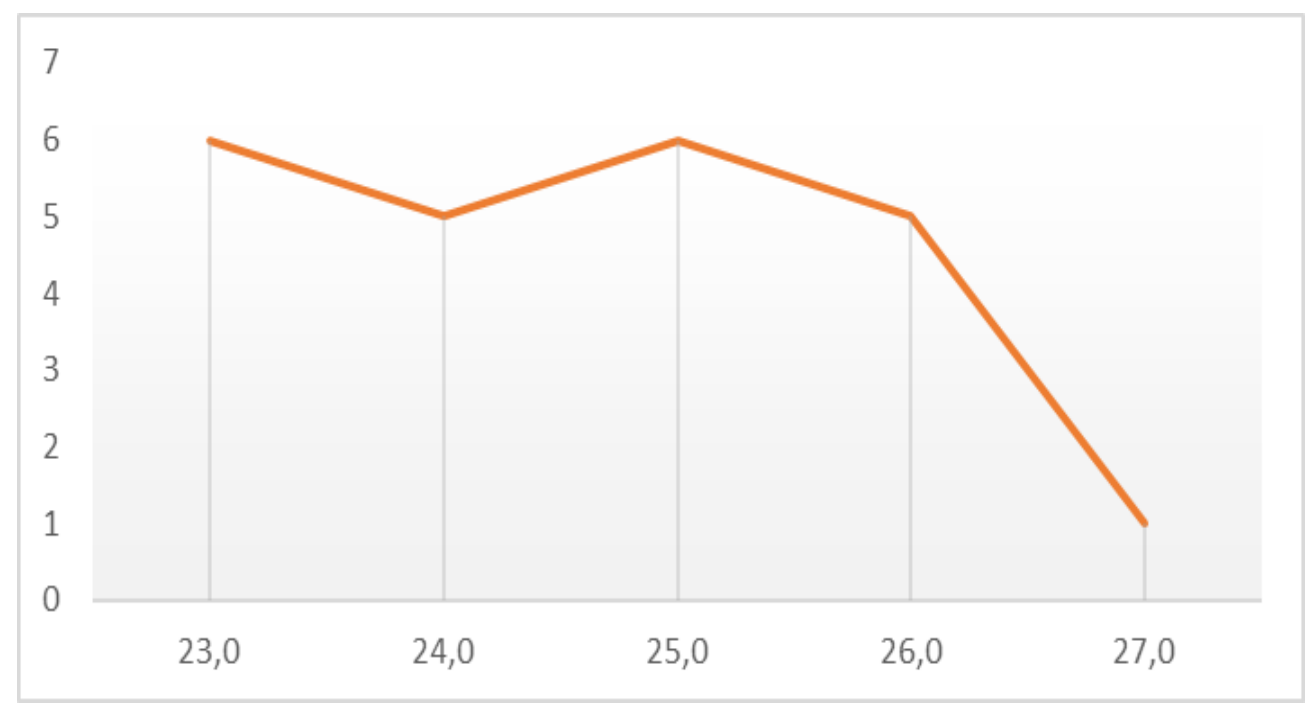

Gambar 1. Grafik polygon data hasil belajar IPS kelompok eksperimen

Dari Gambar 1 terlihat bahwa skor hasil belajar IPS sebagian besar berada pada skor 23 dan 25. Selanjutnya, data akan dikategorikan berdasarkan Mi dan Sdi ke dalam kategori Sangat tinggi, tinggi, sedang, rendah dan sangat rendah.

Berdasarkan data hasil belajar IPS siswa kelompok kontrol dapat disajikan ke dalam bentuk grafik polygon seperti Gambar 2. 


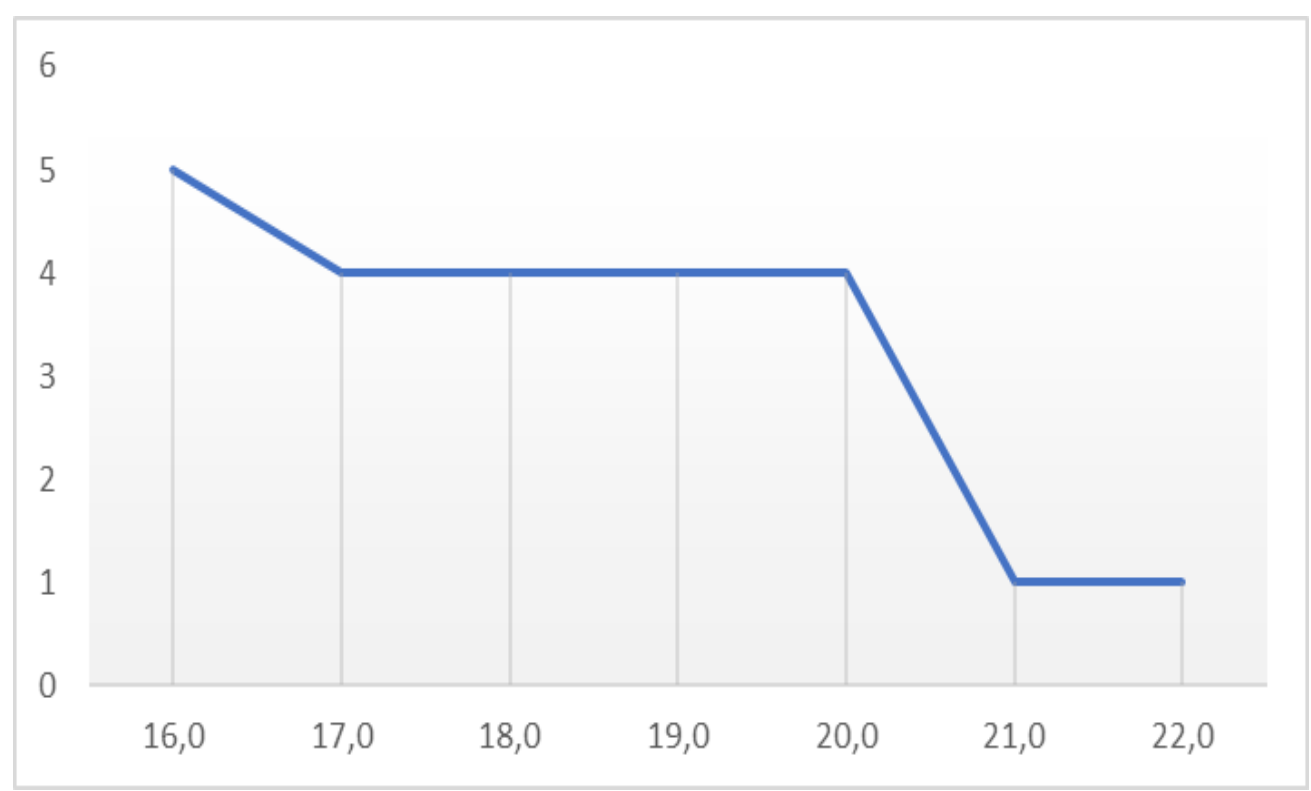

Gambar 2. Grafik polygon data hasil belajar IPS kelompok eksperimen

Dari Gambar 2 terlihat bahwa skor hasil belajar IPS sebagian besar berada pada skor 16. Selanjutnya, data akan dikategorikan berdasarkan Mi dan Sdi ke dalam kategori Sangat tinggi, tinggi, sedang, rendah dan sangat rendah.

Sebelum melakukan pengujian hipotesis dengan menggunakan uji t independent, data yang diperoleh terlebih dahulu dilakukan uji normalitasnya. Hasil pengujian normalitas data hasil belajar IPS siswa kelas eksperimen dapat dilihat pada Table 3 berikut.

Tabel 3. Rangkuman Hasil Uji Normalitasi Data Hasil Belajar

\begin{tabular}{rcrcc}
\hline No & Kelompok Data Hasil Belajar IPS & $\chi^{2}{ }_{\text {hitung }}$ & $\chi^{2}$ tabel & Status \\
\hline 1 & Post-test Eksperimen & 5,92 & 33,92 & Normal \\
2 & Post-test Kontrol & 13,47 & 33,92 & Normal \\
\hline
\end{tabular}

Kriteria pengujian, jika $\chi^{2}{ }_{h i t}<\chi_{\text {tab }}^{2}$ dengan taraf signifikasi $5 \%$ (dk $=$ jumlah kelas dikurangi parameter, dikurangi 1), maka data berdistribusi normal. Sedangkan, jika $\chi_{h i t}^{2} \geq \chi_{t a b}^{2}$, maka sebaran data tidak berdistribusi normal. Berdasarkan hasil perhitungan degan menggunakan rumus Chi-Square, diperoleh data hasil post-test kelompok eksperimen dan kontrol berdistribusi normal. Selanjutnya akan dilakukan uji homogenitas varians.

Uji homogenitas varians antar kelompok bertujuan untuk memeriksa kesamaan varians antar kelompok perlakuan. Dalam penelitian ini, uji homogenitas dilakukan terhadap varians pasangan antar kelompok eksperimen dan kontrol. Uji yang digunakan adalah uji-F dengan kriteria data homogen jika $F_{\text {hit }}<F_{\text {tab }}$. Rekapitulasi hasil uji homogenitas varians antar kelompok eksperimen dan kontrol disajikan pada Tabel 4 berikut.

Tabel 4. Rangkuman Hasil Uji Homogenitas Varians

\begin{tabular}{lllc}
\hline \multicolumn{1}{c}{ Data } & $\mathbf{F}_{\text {hitung }}$ & $\mathbf{F}_{\text {tabel }}$ & Kesimpulan \\
\hline $\begin{array}{l}\text { Post-Test Kelompok Eksperimen dan } \\
\text { Kelompok Kontrol }\end{array}$ & 1,99 & 2,074 & Homogen \\
\hline
\end{tabular}


Berdasarkan Tabel di atas, diketahui $F_{\text {hit }}$ hasil kelompok eksperimen dan kontrol adalah 1,99 sedangkan $\mathrm{F}_{\text {tab }}$ pada $\mathrm{db}_{\text {pembilang }}=22, \mathrm{db}_{\text {penyebut }}=22$, dan taraf signifikansi $5 \%$ adalah 2,074 . Hal ini berarti, varians data hasil belajar IPS kelompok eksperimen dan kontrol adalah homogen.

Setelah pengujian prasyarat terpenuhi selanjutnya dilakukan pengujian hipotesis penelitian $\left(\mathrm{H}_{1}\right)$ dan hipotesis nol $\left(\mathrm{H}_{0}\right)$. Rumusan hipotesisnya adalah sebagai berikut:

$$
H_{0}: \mu_{1}=\mu_{2} \text { melawan } H_{a}: \mu_{1} \neq \mu_{2}
$$

$H_{0}: \mu_{1}=\mu_{2}$ yaitu Hasil Belajar IPS siswa kelas $\mathrm{V}$ yang dibelajarkan dengan model pembelajaran Snowball Throwing sama Hasil Belajar IPS siswa kelas V yang dibelajarkan dengan pembelajaran konvensional.

$H_{a}: \mu_{1} \neq \mu_{2}$ yaitu Hasil Belajar IPS siswa kelas $\mathrm{V}$ yang dibelajarkan dengan model pembelajaran Snowball Throwing tidak sama dengan Hasil Belajar IPS siswa kelas $\mathrm{V}$ yang dibelajarkan dengan pembelajaran konvensional.

Keterangan:

$\mu_{1} \quad$ : rata-rata skor post test siswa yang mengikuti model pembelajaran Snowball Throwing

$\mu_{2} \quad$ : rata-rata skor post test siswa yang mengikuti pembelajaran konvensional.

Jika terbukti bahwa kedua sampel berdistribusi normal dan berasal dari populasi dengan variasi yang homogen, maka dipergunakan analisis uji-t ( $t$-test) dengan taraf signifikansi $5 \%$ dengan rumus penelitian empiris karena $\mathrm{n} 1 \neq \mathrm{n} 2$. Kriteria pengujian jika, maka $\mathrm{H}_{0}$ ditolak dan $\mathrm{H}_{1}$ diterima. Ini berarti terdapat pengaruh yang signifikan. Tetapi jika , maka $\mathrm{H}_{0}$ diterima dan $\mathrm{H}_{1}$ ditolak. Ini berarti tidak terdapat pengaruh yang signifikan. Pengujian dilakukan dengan taraf signifikansi $5 \%$ dengan derajat kebebasan $d k=n_{1}+n_{2}-2$. Rangkuman hasil analisis uji-t ditampilkan pada Tabel 5 berikut.

Tabel 5. Rangkuman Hasil Uji Hipotesisi

\begin{tabular}{|c|c|c|c|c|c|}
\hline Kelompok & $N$ & $\bar{Y}$ & $S_{g a b}^{2}$ & $t_{\text {hitung }}$ & $t_{\text {tabel }}$ \\
\hline $\begin{array}{c}\text { Eksperimen } \\
\text { Kontrol }\end{array}$ & $\begin{array}{l}23 \\
23\end{array}$ & $\begin{array}{l}24,56 \\
18,22 \\
\end{array}$ & 1,516592 & 6,92 & 2,01 \\
\hline
\end{tabular}

Berdasarkan hasil perhitungan pada Tabel 5, diperoleh bahwa $t_{\text {hitung }}>t_{\text {tabel }}$, yang berarti $\mathrm{H}_{0}$ ditolak. Ini artinya hasil belajar IPS siswa kelas $\mathrm{V}$ yang dibelajarkan dengan model pembelajaran Snowball Throwing lebih tinggi daripada kemampuan spasial siswa yang dibelajarkan dengan pembelajaran konvensional.

Hasil analisis data menunjukkan bahwa terdapat pengaruh model pembelajaran Snowball Throwing terhadap hasil belajar IPS siswa kelas V SDN 3 Batur. Tinjauan ini didasarkan pada hasil uji-t dan rata-rata skor hasil belajar siswa. Analisi data menggunakan uji-t, diketahui $t_{\text {hit }}=$ 6,92 dan $t_{\text {tab }}$ pada taraf signifikansi $5 \%=2,01$ hasil perhitungan tersebut menunjukkan bahwa $t_{\text {hitung }}>t_{\text {tabel }}$, sehingga hasil penelitian adalah signifikan. Hal ini berarti, terdapat pengaruh hasil belajar IPS siswa yang dibelajarkan dengan model pembelajaran kooperatif tipe Snowball Throwing dengan siswa yang dibelajarkan pembelajaran Konvensional.

Perbedaan perlakuan antara proses pembelajaran yang menggunakan model Snowball Throwing dan pembelajaran menggunakan model konvensional tentu memberikan dampak yang berbeda terhadap hasil belajar IPS siswa. Penggunaan model Snowball Throwing dalam pembelajaran akan menjadikan siswa aktif. Model pembelajaran ini merupakan model dengan membentuk beberapa siswa menjadi kelompok, setiap kelompok beranggotakan 4-5 siswa. Kemudian guru memberikan materi kepada siswa, setiap ketua kelompok maju kedepan untuk 
mendengarkan arahan dari guru, kemudian ketua kelompok kembali ke kelompoknya masingmasing untuk berdiskusi terkait tentang materi yang akan di pelajarinya. Guru membagikan masing-masing kelompok selembar kertas untuk menuliskan pertanyaan yang menyangkut materi yang sudah dijelaskan. Selanjutnya siswa menggulung kertas tersebut seperti bola, kemudian bola kertas tersebut dilemparkan ke kelompok lain sesuai dengan arahan dari guru. Model Snowball Throwing "memiliki ciri kahas dimana guru hanya menunjuk seorang siswa untuk mewakili kelompoknya tanpa memberi tahu terlebih dahulu siapa yang akan mewakili kelompoknya" (Kurniasih, 2015:78). Selanjutnya siswa yang namanya disebutkan oleh guru dari kelompok tersebut mengangkat tangan dan berdiri untuk menjawab pertanyaan. Kelompok lain yang memiliki jawaban berbeda mennggapi jawaban tersebut. Dengan cara begitu maka semua siswa akan menjadi lebih bersemangat untuk belajar. Pada proses pelaksanaan pembejaran dengan menggunakan model Snowball Throwing guru merasa siswa menjadi lebih termotivasi dan antusias dalam mengikuti pembelajaran. Dan dalam model ini pembagian tugas menjadi jelas ketika mengerjakan tugas, sehingga siswa mendapat peranan masing-masing. Dengan begitu semua siswa di dalam kelas kelas akan memahami dengan betul materi yang sudah mereka pelajari.

Ketika pembelajaran berlangsung, siswa pada kelas eksperimen terlihat memiliki rasa percaya diri yang tinggi. Hal tersebut terlihat saat guru menyebutkan nama secara acak, siswa memiliki rasa percaya diri yang tinggi, karena pembelajaran yang mendapatkan model pembelajaran kooperatif tipe Snowball Throwing mengaruskan siswa untuk aktif alam proses pembelajaran. Siswa yang aktif dalam proses pembelajaran tentu memiliki rasa percaya diri yang tinggi dalam menyampaikan pendapatnya di depan kelas.

Selain memiliki rasa percaya diri yang tinggi, sisa pada kelas eksperimen juga terlihat memiliki motivasi belajar yang tinggi dan mampu bekerjasama dengan teman-temannya dalam proses pembelajaran. Hal tersebut terlihat, ketika siswa tidak hanya belajar menerima materi yang diberikan guru tetapi juga belajar bersama dengan teman sebayanya dan mempertimbangkan jawaban dari kelompok lain. Kemudian, saat guru memanggil nama siswa secara acak, siswa dengan semangatnya mengangkat tangan dan menyampaikan pendapatnya tanpa merasa terpaksa. Pola pembelajaran seperti ini terjadi karena model pembelajaran kooperatif tipe Snowball Throwing merupakan model pembelajaran yang baru pertama kali siswa kenali. Segala sesuatu yang baru dan dapat membuat senang akan dapat menumbuhkan motivasi siswa dalam proses pembelajaran dan menumbuhkembangkan rasa kerjasama siswa. Siswa yang memiliki motivasi yang tinggi ketika mengikuti pembelajaran maka akan dapat meningkatkan hasil belajarnya. Temuan dalam penelitian ini sejalan dengan hasil penelitian yang ditemukan oleh Hendy (2018), bahwa penerapan model pembelajaran Snowball Throwing dapat meningkatkan motivasi berprestasi dan hasil belajar siswa karena model ini sangat membantu siswa dalam melakukan diskusi dan kerjasama antar teman.

$\mathrm{Hal}$ ini berbeda dengan siswa yang dibelajarkan dengan Model Konvensional pada kelas kontrol. Pembelajaran mencirikan pembelajaran yang berpusat pada guru. Secara teoritis, pembelajaran yang menggunakan model konvensional adalah pembelajaran tradisional atau disebut juga dengan metode ceramah, karena sejak dulu metode ini telah dipergunakan sebagai alat komunikasi lisan antara guru dengan anak didik dalam proses belajar dan mengajar. Dalam hal ini, terlihat bahwa pembelajaran kurang maksimal dalam meningkatkan hasil belajar siswa.

Dengan demikian hasil penelitian ini membuktikan bahwa model pembelajaran kooperatif tipe Snowball Throwing memberikan pengaruh terhadap hasil belajar siswa. Tentu saja dalam hal ini hasil belajar siswa meningkat. Hal ini dapat dilihat dari pembelajaran lebih banyak menentukan siswa aktif di dalam kelompoknya sedangkan guru hanya bertugas sebagai fasilitator dan motivator dalam pembelajaran.

Hambatan yang ditemukan ketika dilakukan penelitian pada kelas eksperimen tidak terlalu berarti. Hanya ada beberapa hambatan kecil seperti masih terdapat beberapa siswa yang suka bercanda tetapi hal tersebut sudah dapat ditanggulangi oleh guru dengan memberikan perhatian lebih kepada siswa yang bersangkutan. Sementara hambatan di kelas kontrol lebih banyak ditemukan. Hambatan-hambatan tersebut adalah banyak ditemukan siswa 
yang kurang memperhatikan guru saat menjelaskan materi seperti siswa bermain-main di kelas. Selain itu terdapat pula beberapa siswa yang bercanda pada saat proses pembelajaran berlangsung.

\section{Simpulan dan Saran}

Berdasarkan hasil analisis data, sehingga dapat disimpulkan bahwa terdapat perbedaan yang signifikan hasil belajar IPS antara kelompok siswa yang dibelajarkan dengan model pembelajaran kooperatif tipe Snoswball Throwing dan kelompok siswa yang dibelajarkan dengan model konvensional pada siswa SD kelas V di Gugus II Kecamatan Kintamani Tahun Pelajaran 2018/2019.

\section{Daftar Pustaka}

Agung, A. A. Gede. 2014. Metodologi Penelitian Pendidikan. Malang: Aditya Media.

Agung, A. A. Gede. 2016. Statistika Dasar untuk Pendidikan. Yogyakarta: CV Budi Utama.

Candiasa, I Made. 2010a. Statistika Univariat dan Bivariat Disertai Aplikasi SPSS. Singaraja: Undiksha.

Koyan. 2012. Statistika Pendidikan Teknik Analisis Kuantitatif. Singaraja: Universitas Pendidikan Ganesha Press.

Rusman. 2012. Model - Model Pembelajaran Mengembangkan Profesionalisme Guru. Jakarta: PT. Rajagrafindo Persada.

Sugiyono. 2012. Metode Penelitian Pendidikan (Pendekatan Kuantitatif, Kualitatif dan R\&D. Bandung: Alfabeta.

Susanto, Ahmad. 2013. Teori Belajar dan Pembelajaran di Sekolah Dasar. Jakarta: Kencana Prenada Media Group.

Wahidmurni. 2017. Metodologi Pembelajaran IPS. Maguwohajro: AR-RUZZ Media.

Kurniasih, Imas dan Berlin Sani.2016. Ragam Pengembangan Model Pembelajaran. Jakarta: Kata Pena.

Putra, I. K. S., Sudana, D. N., \& Tastra, I. D. K. (2017). Pengaruh Model Pembelajaran Kooperatif Tipe Snowball Throwing Berbantuan Media Power Point Terhadap Hasil Belajar Ipa. Mimbar Pgsd Undiksha, 5(2).

Wahyuningsih, S. W., Agung, A. A. G., \& Jampel, I. N. (2017). Pengaruh Model Pembelajaran Snowball Throwing Bermediakan Gambar Terhadap Hasil Belajar Ipa Pada Siswa Kelas V Sdn 1 Sangsit Buleleng. Mimbar Pgsd Undiksha, 5(2).

Helmida, H. (2017). Upaya Peningkatan Hasil Belajar Peserta Didik Dalam Pembelajaran Ipa Melalui Model Cooperative Learning Tipe Snowball Throwing Di Kelas Iv Sdn 29 Sungai Limau. Jurnal Manajemen Pendidikan, 2(3), 575-584.

Karningsih, T. (2016). UPAYA Meningkatkan Aktivitas Belajar IImu Pengetahuan Sosial (Ips) Menggunakan Model Pembelajaran Snowball Throwing Pada Siswa Kelas Iv Sd Negeri 2 Sumberjo Kecamatan Klaten Selatan Tahun Pelajaran 2013/2014. Magistra, 28(95). 
Kusumawati, N. (2017). Pengaruh model pembelajaran kooperatif dengan snowball throwing terhadap hasil belajar ipa pada siswa kelas iv sdn bondrang kecamatan sawoo kabupaten ponorogo. Ibriez: Jurnal Kependidikan Dasar Islam Berbasis Sains, 2(1), 1-12 